Ewa Czajka

Uniwersytet Wrocławski

\title{
ANALIZA UMIEJĘTNOŚCI REFLEKSYJNYCH PRZYSZŁYCH NAUCZYCIELI JĘZYKA ANGIELSKIEGO
}

\begin{abstract}
Analysis of the reflective thinking abilities of pre-service teachers
The fact that a successful language instructor has to be a reflective practitioner is undeniable. However, observations made during teacher training courses reveal trainees' reluctance to self-evaluate their conduct and poorly-developed reflective thinking skills. In an attempt to aid the future teachers' progress in this area, a series of written tasks was introduced during a course. These included: self-evaluation of one's strengths and weaknesses, pre and post-microteaching reflections. The analysis of these narratives provides an insight into the trainees' selfevaluation processes and demonstrates a gradual progress in their abilities from descriptive to productive reflective thinking. Thus the results seem to confirm the positive influence of the intervention.
\end{abstract}

Keywords: reflection, self-evaluation, teacher training, methodology of teaching English, micro lesson

Słowa kluczowe: refleksja, autoewaluacja, edukacja nauczycieli, metodyka nauczania języka angielskiego, mikro-lekcja

\section{Wprowadzenie}

Istota refleksji w procesie nauczania języka obcego jest niepodważalna. Wielu specjalistów zajmujących się tym zagadnieniem określa refleksję jako nie tylko ważną, ale wręcz niezbędną dla rozwoju zawodowego nauczyciela (np. Gabryś-Barker, 2012; Jay, 2003; Osterman i Kottkamp, 2004; Russell, 2005; Witkowska, 2009; Zawadzka, 2004). Także w Rozporządzeniu Ministra Nauki i Szkolnictwa Wyższego, dotyczącym standardów kształcenia przygotowują- 
cego do wykonywania zawodu nauczyciela (2012: 3), odnajdujemy zapis, który jasno precyzuje, iż absolwent kursów i zajęć metodycznych „posiada cechy refleksyjnego praktyka (...), dokonuje oceny własnych kompetencji i doskonali umiejętności w trakcie realizowania zadań pedagogicznych". Jak zauważa Witkowska (2009: 130), „kształcenie umiejętności refleksyjnego myślenia jest już zatem wpisane w standardy kształcenia nauczycielskiego".

Wśród studentów uczęszczających na zajęcia z metodyki języka obcego spotkać możemy osoby, którym refleksja przychodzi niejako w sposób naturalny i niewymagający z ich strony świadomego wysiłku. Niemniej jednak liczną grupę przyszłych nauczycieli stanowią osoby, dla których głęboki namysł oraz analiza skuteczności i konsekwencji własnych działań dydaktycznych jest procesem trudnym i nieoczywistym. Czy oznacza to, że absolwenci ci w zderzeniu z rzeczywistością szkolną skazani są na porażkę? Czy można ukierunkować rozwój studentów w taki sposób, aby pomimo początkowych trudności w przyszłości mogli stać się autonomicznymi i refleksyjnymi praktykami?

Celem artykułu jest przedstawienie działań podjętych przez prowadzącą zajęcia z metodyki języka angielskiego, mających umożliwić studentom rozwój ich zdolności refleksyjnych. Przedstawiona analiza nie jest rezultatem uprzednio zaplanowanej procedury badawczej, stanowi raczej raport z interwencji, będących odpowiedzią na zauważone problemy. Opisane czynności miały miejsce na przestrzeni dwóch semestrów roku akademickiego 2012/1013 i odnoszą się do grupy studentów II roku Filologii Germańskiej Uniwersytetu Wrocławskiego, uczestniczących w zajęciach z metodyki, które miały przygotować ich do nauczania języka angielskiego, a więc ich języka trzeciego (L3). Zaproponowane rozwiązania były w dużej mierze zainspirowane badaniem Witkowskiej (2009), w którym autorka udowadnia, że rozwijanie umiejętności refleksyjnego myślenia „jest możliwe i przynosi efekty w ramach kształcenia pedagogicznego" (Witkowska, 2009: 138).

\section{Rozpoznanie problemu}

Jednym z zadań, z jakim uczestnicy zajęć z metodyki nauczania języka angielskiego muszą się zmierzyć, jest zaplanowanie i przeprowadzenie mikro-lekcji. $\mathrm{Na}$ tym etapie studenci po raz pierwszy mają sposobność odniesienia się do już nabytej wiedzy teoretycznej i wykorzystania jej w praktyce. W celu opisania problemu wymagającego interwencji posłużę się podziałem na etapy dokonywania refleksji zaproponowanym przez Brzezińską (1999: 47). 


\subsection{Planowanie}

Analiza myślenia refleksyjnego studentów na tym etapie jest możliwa jedynie w odniesieniu do osób, które swoje plany konsultują z prowadzącym zajęcia. Chęć rozwiania wątpliwości, czy uzyskania potwierdzenia swoich wstępnych założeń niewątpliwie świadczy o angażowaniu przez studentów procesów myślenia refleksyjnego. Należy jednak dodać, że zdecydowana większość uczestników zajęć decyduje się na pracę całkowicie samodzielną.

\subsection{Realizacja planu}

Nie może dziwić ani zaskakiwać fakt, że na tym etapie doskonalenia zawodowego realizacja planu nie jest idealna. Dla większości studentów spojrzenie na klasę z perspektywy nauczyciela jest doświadczeniem całkowicie nowym. Wydaje się, że studenci dążą przede wszystkim do niezakłóconej realizacji całości planu, skupiając uwagę przede wszystkim na sobie i ograniczając interakcję z grupą do niezbędnego minimum. Niezwykle rzadko zaobserwować można zachowania świadczące o refleksji w działaniu.

\subsection{Ewaluacja}

Bezpośrednio po przeprowadzeniu mikro-lekcji studenci angażowani są w dyskusję mającą na celu omówienie jej przebiegu. Obserwacje poczynione podczas zajęć pozwalają stwierdzić, że refleksja na tym etapie jest nieefektywna i niewystarczająca. Po pierwsze, studenci-obserwatorzy niechętnie biorą udział w dyskusji. Nieliczne osoby, które zabierają głos, ograniczają się do lakonicznych i mało konstruktywnych pochwał, np. „Super, podobało mi się". Wynikać to może z braku podstaw wiedzy teoretycznej i/lub umiejętności refleksyjnych. Równie prawdopodobne wydaje się także, że studenciobserwatorzy niechętnie komentują wystąpienia swoich kolegów i koleżanek, postrzegając rolę ewaluatorów jako krytyków, których zadaniem jest przede wszystkim zwrócenie uwagi na błędy. Ewaluacja jest więc rozumiana jako proces o konotacji negatywnej. Ponadto studenci, którzy przeprowadzili mikro-lekcję również nie biorą aktywnego udziału w dyskusji. Co więcej, nie przejawiają oni zainteresowania partycypacją w dalszej części zajęć, co może oznaczać, że przeprowadzenie mikro-lekcji stanowi dla nich cel sam w sobie. 


\section{Planowanie działań interwencyjnych}

Przedstawiona powyżej sytuacja jasno pokazuje, że studenci nie są świadomi istoty refleksji w procesie rozwoju zawodowego nauczyciela. Nie rozumieją oni, czym jest i czemu właściwie służy myślenie refleksyjne. Zdają się nie dostrzegać, że „bez niezbędnej refleksji i interpretacji własnego działania niemożliwe jest przyswajanie nowej wiedzy i burzenie starych i często nieefektywnych przyzwyczajeń" (Zawadzka, 2004: 301). Studenci upatrują celu zadania w samej realizacji zamierzonego planu, a doświadczenie to, pozbawione analizy skuteczności podjętych działań, nie jest przecież przyczynkiem do rozwoju i jako takie przynosi niewiele pożytku (Arends, 1994: 497; Witkowska, 2009: 138). Niezwykle niepokojącym zjawiskiem wydaje się również utożsamianie przez studentów myślenia refleksyjnego z dokonywaniem surowej, ujemnej oceny własnych działań. Błędne, pejoratywne pojmowanie ewaluacji ma znamienne skutki, wpływające na jakość kształcenia przyszłych nauczycieli. Etymologia wyrazu ewaluacja uzmysławia pozytywnie wartościującą konotację procesu:

- e-valesco, -ere, -ui - stawać się silnym, potężnieć (Słownik łacińskopolski PWN, 1977)

- evaeleo, -ere - móc, zdołać; e-valesco, - ere, -ui - wzmocnić się, nabrać siły, spotężnieć; móc, być zdolnym, zdołać, potrafić (Słownik łacińsko-polski PWN, 1962).

W odniesieniu do praktyki pedagogicznej ocena działań podjętych przez siebie i innych może prowadzić do utrwalenia zachowań, które w naszej ocenie są skuteczne albo modyfikacji lub odrzucenia tych, które uznamy za nietrafione. We wszystkich trzech przypadkach ewaluacja prowadzi do zwiększenia swoich kompetencji a zatem oznacza rozwój i rozumiana w ten sposób powinna stanowić główny cel mikro-lekcji.

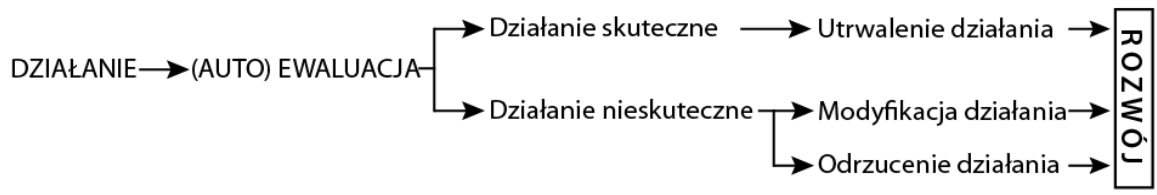

Wykres 1: Refleksja nad działaniem.

Wykres 1 przedstawia schemat refleksji nad działaniem, który został przedstawiony i omówiony ze studentami. Jest to oczywiście bardzo ograniczone ujęcie refleksji, może jednak stanowić punkt wyjścia do dalszego zgłębiania znaczenia pojęcia, prowadząc $w$ rezultacie do rozwinięcia zdolności myślenia refleksyjnego uczestników zajęć z metodyki. 


\subsection{Zadanie pierwsze: refleksja nad przeprowadzoną mikro-lekcją}

W celu udoskonalenia procesu kształcenia przyszłych nauczycieli prowadząca zajęcia zaproponowała studentom dokonanie autorefleksji $\mathrm{w}$ formie pisemnej. Instrukcje do zadania, zawierające teoretyczne wprowadzenie wyjaśniające, czym jest i czemu służy refleksja, zostały przedstawione i omówione podczas zajęć. Prace były nieobowiązkowe i nieograniczone kryteriami ilościowymi czy treściowymi, pozwalając studentom na całkowitą dowolność formy i sposobu wyrażania. Warunkiem przyjęcia pracy było dostarczenie jej nie później niż jeden tydzień po przeprowadzeniu mikro-lekcji.

Spośród wszystkich studentów w grupie $(\mathrm{N}=26)$ jedynie jedenaście osób $(n=11)$ podjęło się zadania. Pod względem ilościowym większość prac nie przekroczyła objętością jednego akapitu. W odniesieniu do treści zauważyć można skłonność studentów do ograniczania refleksji do zdawkowego opisu zaistniałych wydarzeń, bez analizy przyczynowo-skutkowej, wyciągania wniosków oraz formułowania planów na przyszłość. Zarówno brak konstruktywnych uwag jak i lakoniczny charakter pisemnej wypowiedzi spowodowały, iż prace w niewielkim stopniu odzwierciedlały treści zawarte w arkuszach obserwacyjnych, wypełnianych przez prowadzącą zajęcia w trakcie przeprowadzania przez studentów mikro-lekcji. Wszystkie refleksje bez wyjątku odnosiły się krytycznie do przeprowadzonych prezentacji, podając nieumiejętność opanowania stresu jako główną przyczynę niepowodzenia.

\subsection{Zadanie drugie: przygotowanie do refleksji pisemnej}

Niezadowalająca jakość pierwszej refleksji pisemnej wskazała na konieczność dodatkowej interwencji, mającej umożliwić aktywizację i pogłębienie myślenia refleksyjnego uczestników kursu. Prowadząca zajęcia zaproponowała wykonanie zadania, poprzedzającego kolejną prezentację przyszłych nauczycieli na forum grupy. Studenci zostali poproszeni o pisemną odpowiedź na dwa pytania. Pierwsze wymagało od nich zastanowienia się i określenia już opanowanej wiedzy, posiadanych zdolności i cech osobowościowych, które będą przydatne w wykonywaniu obowiązków nauczyciela, skutecznym przeprowadzaniu lekcji języka angielskiego i umiejętnym kierowaniu pracą uczniów. Drugie pytanie dotyczyło wiedzy studentów, ich zdolności i cech osobowościowych wymagających jeszcze nauki i doświadczenia. Oba pytania miały formę otwartą, po raz kolejny pozwalając uczestnikom zajęć na dowolność w formie i treści pisemnej wypowiedzi. Praca, w tym przypadku obowiązkowa, była przyjmowana pod warunkiem złożenia jej nie później niż jeden tydzień przed przeprowadzaną mikro-lekcją. Tabele 1 i 2 prezentują zgromadzone dane: 
Ewa Czajka

\begin{tabular}{|l|l|}
\hline $\begin{array}{l}\text { Liczba studentów } \\
(\mathrm{N}=22)\end{array}$ & Udzielone odpowiedzi \\
\hline 13 & Cierpliwość \\
\hline 12 & Komunikatywność \\
\hline 8 & Wyrozumiałość \\
\hline 5 & Chęć nauczania/pomagania \\
\hline 5 & Chęć pracy z dziećmi \\
\hline 5 & Zainteresowanie ludźmi \\
\hline 5 & Serdeczność/bycie przyjaznym \\
\hline
\end{tabular}

Tabela 1: Posiadana wiedza, zdolności i cechy osobowościowe pomocne w nauczaniu języka angielskiego.

Na pytanie o już opanowaną wiedzę, posiadane zdolności i cechy osobowościowe wśród najczęściej otrzymanych odpowiedzi znalazły się: serdeczność/bycie przyjaznym $(n=5)$, zainteresowanie ludźmi $(n=5)$, chęć pracy $z$ dziećmi $(n=5)$, chęć nauczania/pomagania $(n=5)$, wyrozumiałość $(n=8)$ i komunikatywność $(n=12)$. Aż trzynaście osób $(n=13)$ wymieniło cierpliwość jako swoją główną zaletę. Pomimo otwartej formy pytania większość uczestników zajęć udzieliła takich samych odpowiedzi, co sugeruje, że na tym etapie rozwoju studenci podobnie postrzegają swoje atuty. Zupełny brak odniesień do posiadanej wiedzy czy zdolności pokazuje, że przyszli nauczyciele języka angielskiego dopatrują swoich mocnych stron jedynie we względnie ukształtowanych cechach osobowościowych.

\begin{tabular}{|l|l|}
\hline $\begin{array}{l}\text { Liczba studentów } \\
(\mathrm{N}=22)\end{array}$ & Udzielone odpowiedzi \\
\hline 13 & Pokonanie nieśmiałości/opanowanie stresu \\
\hline 11 & Poprawna wymowa języka angielskiego \\
\hline 9 & Przeprowadzanie zajęć według zamierzonego planu \\
\hline 9 & Utrzymywanie dyscypliny \\
\hline 6 & Kompetencja językowa \\
\hline 5 & $\begin{array}{l}\text { Planowanie lekcji (kolejność etapów, dobór materiałów } \\
\text { dydaktycznych odpowiednich do wieku i poziomu uczniów) }\end{array}$ \\
\hline 5 & Kontrolowanie czasu podczas prowadzenia lekcji \\
\hline 3 & Wydawanie poleceń i instrukcji \\
\hline 3 & Utrzymywanie kontaktu wzrokowego \\
\hline
\end{tabular}

Tabela 2: Wiedza, zdolności i cechy osobowościowe wymagające nauki i doświadczenia.

Na liście umiejętności wymagających dalszej pracy i doświadczenia znalazły się: utrzymywanie kontaktu wzrokowego z uczniami $(\mathrm{n}=3)$, wydawanie poleceń $i$ instrukcji $(\mathrm{n}=3)$, kontrolowanie czasu $(\mathrm{n}=5)$, planowanie lekcji $(\mathrm{n}=5)$, kompetencja językowa $(\mathrm{n}=6)$, utrzymywanie dyscypliny w klasie $(\mathrm{n}=9)$, przeprowadzanie zajęć według zamierzonego planu $(\mathrm{n}=9)$, poprawna wymowa 
$(n=11)$. Pomimo że największa liczba studentów ( $n=13$ ) wymieniła pokonanie nieśmiałości/opanowanie stresu, zgromadzone dane wyraźnie pokazują, że dokonując refleksji nad swoimi słabymi stronami, przyszli nauczyciele skupiają się głównie na konkretnych zdolnościach. W tym przypadku wypowiedzi studentów w dużo większym stopniu odzwierciedlają tematy omawiane na zajęciach. Wydaje się, że studenci są świadomi swoich braków i konieczności doskonalenia warsztatu, przede wszystkim w odniesieniu do kierowania grupą (ang. classroom management). Ponadto przyszli nauczyciele języka angielskiego, będącego ich językiem trzecim (L3), dostrzegają konieczność dalszej pracy w celu zwiększenia kompetencji językowej, w tym poprawnej wymowy.

\subsection{Zadanie trzecie: przewidywane problemy}

Podczas zajęć, bezpośrednio przed przeprowadzeniem mikro-lekcji, studenci zostali poproszeni o zastanowienie się nad możliwymi problemami, które mogą wystąpić podczas prezentacji (ang. anticipated probems). Indywidualna refleksja miała formę krótkiej wypowiedzi pisemnej. Prace miały pomóc studentom w wykonaniu zadania czwartego, a zatem nie zostały zebrane przez prowadzącą zajęcia.

\subsection{Zadanie czwarte: refleksja nad przeprowadzoną mikro-lekcją}

Ostatnim zadaniem studentów było dokonanie refleksji pisemnej po przeprowadzeniu drugiej mikro-lekcji. Forma i kryteria pracy pozostały niezmienione (por. 1.3). Tym razem jednak instrukcje do zadania zawierały sugestię odniesienia się do problemów przewidzianych przed prezentacją (por. 3.3). Wykonanie zadania było obowiązkowe, a jego wyniki miały stanowić $20 \%$ oceny końcowej, o czym studenci zostali poinformowani na początku semestru.

Efekt końcowy pracy studentów na tym etapie był zupełnie odmienny od wyników refleksji pisemnej, jakiej podjęli się pół roku wcześniej. Pod względem formy część prac była dużo bardziej rozbudowana, w wielu przypadkach przekraczając objętością kilka stron. Prace były bardziej starannie i logicznie rozplanowane. Większość rozpoczynała się obszernym i dokładnym opisem procesu planowania i przygotowywania się do przeprowadzenia mikro-lekcji. Kilka osób opisało ten etap jako niezmiernie trudny i zarazem sprawiający wiele satysfakcji. Wszyscy studenci odnieśli się także do przewidywanych problemów, sformułowanych jeszcze przed przeprowadzeniem mikro-lekcji. Wymieniono tu głównie obawy przed nieumiejętnością zapanowania nad głosem, błędami w wymowie i błędami gramatycznymi, a także możliwością zapomnienia i pominięcia jednej z zaplanowanych czynności. 
Jako główną przyczynę możliwych problemów uczestnicy kursu podawali lęk przed wystąpieniami publicznymi. Podkreślali zwłaszcza własne obawy przed brakiem zainteresowania i współpracy ze strony grupy, na przykład ${ }^{1}$ :

Piosenka o ciuchach jest trochę prymitywna i bałam się, że grupa nie będzie chciała uczestniczyć w jej śpiewaniu. Miałam nadzieję, że grupa nie będzie głośna. Nie lubię i nie umiem uciszać znajomych.

Bałam się, że nie będę umiała utrzymać dyscypliny. Nie lubię występować przed znajomymi. Łatwiej byłoby gdybym występowała przed małymi dziećmi.

Bałam się, że grupa nie doceni moich starań i będzie znudzona prezentacją, lub że nie powstrzyma się od głupich komentarzy.

Studenci zauważyli, że ich obawy dotyczące zachowania obserwatorów nie potwierdziły się. Wiele osób wyraziło zdziwienie tym, że wszyscy chętnie brali udział w zaproponowanych zadaniach. Nie bez znaczenia wydaje się również, że tym razem studenci-obserwatorzy dużo chętniej komentowali wystąpienia swoich kolegów i koleżanek.

Prace były w dużej mierze analityczne i w przeciwieństwie do poprzednich refleksji, nie ograniczały się jedynie do opisu zaistniałych sytuacji. Ponadto w kilku wypowiedziach pisemnych znaleźć można elementy świadczące o próbach stosowania przez studentów refleksji w działaniu, na przykład:

Przed wystąpieniem obawiałam się zmiany tonu mojego głosu i faktycznie miałam wrażenie, że mówię odrobinę wyższym głosem, co zapewne wynikało ze stresu.

Byłam mile zaskoczona tym, że mimo lekkiej niepewności głośno i wyraźnie mówiłam, a moje gesty pomagały mi w wydawaniu poleceń.

Wydawało mi się, że mówię za szybko i przez to odrobinę niewyraźnie.

W refleksjach napisanych przez uczestników kursu znajdziemy wiele podobnych uwag. Nie świadczą one o bezpośredniej modyfikacji działań podczas zajęć. Wydaje się jednak prawdopodobne, że próba takiej modyfikacji, niekoniecznie efektywna, faktycznie miała miejsce. Świadczy o tym na przykład wypowiedź jednej ze studentek:

${ }^{1}$ Wszystkie wypowiedzi studentów, przytoczone $w$ artykule, są przedstawione w wersji oryginalnej, bez ingerencji stylistycznej autorki. 
Gdy próbowałam wytłumaczyć na czym polega gra, straciłam całkowicie kontrolę nad tym co i jak mówiłam (...) najgorsze jest to, że sama sobie przerwałam tę instrukcję.

Wydaje się więc, że refleksja w działaniu wymaga od studentów dalszej praktyki i doświadczenia. Niemniej jednak, sam fakt spostrzeżenia problemu oznacza, że studenci już na tym etapie podejmują próby dokonania samoobserwacji. Nie skupiają się już jedynie na tym co robią, ale też w jaki sposób podjęte przez nich czynności są wykonywane.

Zdecydowana większość prac odnosiła się do przeprowadzonych mikro-lekcji pozytywnie, opisując je jako trudne wyzwanie, dzięki któremu mieli okazję dostrzec elementy wymagające poprawy i w rezultacie wiele się nauczyć. Świadczą o tym na przykład następujące fragmenty wypowiedzi:

Cieszę się, że miałam możliwość sprawdzenia się w takiej symulacji. Zmusza to do wyciągnięcia wniosków.

Mam teraz wrażenie, że najbardziej przydatna będzie dalsza praktyka, bo ćwiczenie czyni mistrza. Czuję też, że każde moje wystąpienie będzie lepsze od poprzednich.

Pomimo tego, że było kilka błędów w moim wystąpieniu, jestem z niego zadowolona, bo wiem, że w następnych prezentacjach już ich nie powtórzę.

W podsumowaniu prac większość studentów przedstawiła plan dalszego rozwoju. Tak jak w poprzednich refleksjach, wiele osób wyraziło wątpliwości dotyczące ich kompetencji językowej, dostrzegając konieczność pracy nad podwyższeniem poziomu języka angielskiego, podkreślając zwłaszcza aspekt poprawnej wymowy. W odniesieniu do planowania zajęć w przyszłości i związanych z tym aspektów wymagających dalszej pracy i nauki najczęściej wymieniono:

- staranny dobór materiałów dydaktycznych (ilość i adekwatność w stosunku do wieku i poziomu uczniów),

- staranne i dokładne przemyślenie kolejności etapów i zadań,

- przemyślenie celowości każdego zadania,

- zaplanowanie wykorzystania oraz rozmieszczenia materiału na tablicy,

- przećwiczenie wydawania instrukcji,

- przećwiczenie wymowy prezentowanego słownictwa.

W odniesieniu do przeprowadzania zajęć w przyszłości najczęściej wymienianymi aspektami, którym studenci planowali poświęcić więcej uwagi były: kontro- 
lowanie gestów (koordynacja gestów i słowa mówionego) i czasu, a także staranne pisanie na tablicy.

\section{Podsumowanie}

W artykule przedstawiono działania umożliwiające studentom - przyszłym nauczycielom języka angielskiego, pogłębienie ich refleksji metodycznej. Analiza rezultatów zadań, jakich podjęli się uczestnicy zajęć z metodyki, zdaje się potwierdzać, że interwencja przyniosła pożądany efekt. Porównanie umiejętności refleksyjnych studentów na początku oraz na końcu kursu koreluje z wynikami badania Witkowskiej (2009), w którym autorka stwierdza, że różne formy ćwiczeń inspirujących do refleksji stanowią potencjalny czynnik aktywizujący i podnoszący umiejętności studentów do namysłu oraz analizy własnych działań dydaktycznych. Ponadto wydaje się, że postawienie przed studentami zadania dokonania refleksji w formie pisemnej powoduje, że są oni bardziej zaangażowani w omawianie prezentacji podczas zajęć. Przyszli nauczyciele postrzegają dyskusję na tym etapie jako wartościowe źródło uwag i wskazówek oraz jako punkt wyjściowy do samodzielnego napisania pracy.

Rozbicie zadania na mniejsze etapy pozwoliło studentom usystematyzować procesy myślowe i nadać ich refleksjom logiczny porządek. Większość studentów wykorzystała prace pisemne do podzielenia się przemyśleniami dotyczącymi ich preferencji, największych trudności i obaw. Refleksje dały im okazję do przemyślenia i uzmysłowienia sobie własnych zalet oraz obszarów wymagających dalszej praktyki, tym samym przyczyniając się do wskazania kierunku rozwoju zawodowego. Świadczy o tym fragment pracy jednej z uczestniczek zajęć:

Przeprowadzenie prezentacji dało mi wiele do myślenia, bo o ile wcześniej zakładałam, że w przyszłości lepiej będzie mi się pracowało z dorosłymi, o tyle teraz przekonałam się do dzieci.

Nie bez znaczenia wydaje się również użyteczność refleksji pisemnych jako źródła wiedzy o studentach. Lektura prac umożliwia dogłębne poznanie grupy, szczególnie tych osób, które z różnych powodów nie biorą aktywnego udziału w zajęciach i nie korzystają z konsultacji indywidualnych. Ponadto prace stanowią niezwykle cenną informację zwrotną na temat wiedzy, jaką studenci opanowują podczas zajęć. Uzmysławiają prowadzącym, co studenci najlepiej zapamiętują, czemu poświęcają najwięcej uwagi i co postrzegają za najbardziej istotne. Informacje te umożliwiają ewaluację efektywności zajęć z metodyki, wskazując kierunek możliwych modyfikacji w celu podniesienia jakości instrukcji. Wydaje się więc, że refleksja pisemna stanowi potencjalny 
impuls do rozwoju nie tylko dla studentów - przyszłych nauczycieli języka obcego, ale także dla samych prowadzących zajęcia.

\section{BIBLIOGRAFIA}

Arends, R. I. 1994. Uczymy się nauczać. Warszawa: Wydawnictwa Szkolne i Pedagogiczne. Brzezińska, A. I. 1999. „Refeksja w dzialalności nauczycieli” (w:) O nowe podejście w kształceniu nauczycieli (red. A. I. Brzezińska, D. Klus-Stańska i A. Strzelecka). Warszawa: Ministerstwo Edukacji Narodowej: 37-52.

Gabryś-Barker, D. 2012. Reflectivity in Pre-service Teacher Education. A Survey of Theory and Practice. Katowice: Wydawnictwo Uniwersytetu Śląskiego.

Jay, J. K. 2003. Quality Teaching. Reflection as the Heart of Practice. Lanham, MD: Scarecrow Press.

Osterman, K. P. i R. B. Kottkamp. 2004. Reflective Practice for Educators: Improving Schooling through Professional Development. Thousand Oaks, CA: Corwin Press.

Rozporządzenie Ministra Nauki i Szkolnictwa Wyższego z dnia 17 stycznia 2012 r. dotyczące standardów kształcenia przygotowującego do wykonywania zawodu nauczyciela.

Russell, T. 2005. „Can reflective practice be taught?”. Reflective Practice 6 (2), 199-204. Słownik tacińsko-polski. 1962. (red. M. Plezi). Warszawa: PWN.

Stownik łacińsko-polski. 1977. (red. K. Kumaniecki) Warszawa: PWN.

Witkowska, M. 2009. „Refleksyjny student - refeksyjny praktyk. Kształcenie myślenia refleksyjnego przyszłych nauczycieli języka angielskiego" (w:) Nauczyciel języków obcych dziś i jutro (red. M. Pawlak, A. Mystkowska-Wiertelak i A. Pietrzykowska). Poznań-Kalisz: Wydawnictwo UAM: 129-140.

Zawadzka, E. 2004. Nauczyciele języków obcych w dobie przemian. Kraków: Impuls. 